\title{
Haematological and Biochemical Variations in Cervico-Facial Cellulitis of Dental Origin in the City of Ouagadougou (Burkina Faso)
}

\author{
Wendpouiré Patrice Laurent Guiguimdé1,2*, Kouamé Patrice Attogbain ${ }^{3}$, Jocelyne V. W. Garé1,2, \\ Yamsoulougri C. L. Ouédraogo ${ }^{4}$, Souleymane Bougoum ${ }^{1,2}$, Mathieu Millogo ${ }^{1,2}$, Tarcissus Konsem ${ }^{1,2}$ \\ ${ }^{1}$ Training and Research Unit in Health Sciences (UFR/SDS), Joseph Ki Zerbo University, Ouagadougou, Burkina Faso \\ ${ }^{2}$ Department of Odontostomatology and Maxillofacial Surgery, Yalgado Ouédraogo University Hospital, Ouagadougou, \\ Burkina Faso \\ ${ }^{3}$ Department of Surgery, UFR of Odonto-Stomatology, Félix Houphouët-Boigny University of Abidjan, Abidjan, Republic of Côte \\ d'Ivoire \\ ${ }^{4}$ Department of Odontostomatology and Maxillofacial Surgery, Bogodogo University Hospital Center, Ouagadougou, \\ Burkina Faso \\ Email: *guiguimdew@yahoo.fr
}

How to cite this paper: Guiguimdé, W.P.L. Attogbain, K.P., Garé, J.V.W., Ouédraogo, Y.C.L., Bougoum, S., Millogo, M. and Konsem, T. (2021) Haematological and Biochemical Variations in Cervico-Facial Cellulitis of Dental Origin in the City of Ouagadougou (Burkina Faso). Open Journal of Stomatology, 11, 387-398.

https://doi.org/10.4236/ojst.2021.1110034

Received: August 30, 2021

Accepted: September 27, 2021

Published: September 30, 2021

Copyright (c) 2021 by author(s) and Scientific Research Publishing Inc. This work is licensed under the Creative Commons Attribution International License (CC BY 4.0).

http://creativecommons.org/licenses/by/4.0/ (c) (i) Open Access

\begin{abstract}
Background: Cervicofacial cellulitis is a severe infection and is responsible for a major disruption of host homeostasis. The aim of this work was to describe the haematological and biochemical variations of cervico-facial cellulitis. Methods: This was a cross-sectional study conducted from 1 January to 31 December 2020. All patients hospitalized for cervico-facial cellulitis of dental origin were included in the study. The usual parameters of descriptive statistics were estimated for each variable. Results: Our sample consisted of 166 patients. The average age of patients with cervicofacial cellulitis in our study was $39.9 \pm 15.39$ years. Red blood cell count was low in $55.5 \%$ of patients and hyperleukocytosis was noted in $89.16 \%$ of patients. Platelets were normal in $43.14 \%$ of patients and $78.43 \%$ of patients had a low haematocrit (haemodilution). Anemia was noted in $64.7 \%$ of patients. In addition, $61.0 \%$ of patients had elevated uricemia and $31.17 \%$ had elevated creatinemia. Conclusion: Cellulitis is still a common condition in less privileged environments. Its diagnosis can be guided by clinical and biological findings. Consistent education of the population on oral health, and the control of biological disorders that result from it, are sufficient to greatly reduce its prevalence and the appearance of complicated forms.
\end{abstract}

\section{Keywords}

Cervicofacial Cellulitis, Teeth, Haematological Variations, Biochemical 
Variations, Ouagadougou

\section{Introduction}

Cervicofacial cellulitis (CCF) or fasciitis is severe infection, sometimes necrotizing, often following a common infection, usually polymicrobial [1]. Most of the time they are due to odontogenic or pharyngeal origin, involving the aerobic and anaerobic commensal flora of the oral cavity [2]. Their prevalence is higher in young adults aged 16 - 35 years (81\%) of male and disadvantaged populations with poor oral hygiene are the most exposed [3]. Many associated factors have a variable impact on the occurrence and/or clinical picture of this disease.

Cervicofacial cellulitis is responsible for a major disturbance of the biological homeostasis of the host individual, resulting in a rich and varied clinical and topographical symptomatology [4] [5] [6] [7] [8]. The biological disorders induced by cellulitis must be associated with those caused by comorbidities that may interact with it and be responsible for the appearance of severe forms [9]. The knowledge of the biological modifications consecutive to CCF in our context would allow us to detect the repercussion of CCF on the organism of the affected subjects and thus to prevent the appearance of complicated forms but also to detect the responsible germs and to propose an adapted and effective treatment.

Although cervicofacial cellulitis has already been the subject of several studies [10] [11] [12], none of them has focused on the hematological and biochemical aspects of this condition in Burkina Faso, hence the interest of our study. The general objective of this work was to describe the hematological and biochemical variations of cervicofacial cellulitis due to dental origin.

\section{Material and Methods}

Our study was conducted in the Stomatology and Maxillofacial Surgery (S/CMF) departments of the Yalgado Ouédraogo University Hospital (CHU-YO) and the Bogodogo University Hospital (CHU-B).

This was a descriptive cross-sectional study. Data were collected from January 1 to December 31, 2020. All patients hospitalized for cervicofacial cellulitis of dental origin, regardless of sex or age, in whom biological examinations were performed and consent was obtained, were included in the study.

The data were collected using a collection form developed for this purpose (attached). The variables studied included sociodemographic data, clinical data, hematological and biochemical data and management data. All hematological and biochemical variables were recorded with thresholds defined in three modalities (high value, normal value, and low value).

Data entry was done using EPIDATA software. The analysis, which was done using R software version 4.1.0, consisted of a descriptive analysis of the data. The usual parameters of descriptive statistics were estimated for each variable. These 
were the proportions for the qualitative variables, the mean and the standard deviation for the quantitative variables whose distribution was normal.

The anonymity of the patients and the confidentiality of collected information were preserved. No identification data were recorded in the database or used in the analysis.

\section{Results}

Our sample consisted of 166 patients, 156 of whom consulted at UHC-YO and 10 at UHC-B.

\section{Socio-demographic characteristics}

The average age of the patients with CCF in our study was $39.9 \pm 15.39$ years with extremes of 7 and 82 years. The age groups of 21 to 40 years represented slightly more than half $(53 \%)$ of the patients (Figure 1 ). Male patients represented $72.29 \%$ of the sample, a sex ratio of 2.61 . Regarding marital status, $78.31 \%$ of the patients were in couples. Most of them (51.81\%) did not attend school and were self-employed (66.87\%) (professionals, farmers). The indigent represented $58.04 \%$ of the cases and only $(1.2 \%)$ of the patients had health insurance. There were $1.8 \%$ of patients coming from abroad, particularly from Côte d'Ivoire. Among patients living in Burkina Faso, 70.48\% lived in urban areas (Table 1).

\section{Clinical characteristics}

Among the 166 patients in our study, pain was reported to be the reason for consultation in $92.2 \%$ of cases. The delay of consultation was one week for $80.1 \%$ and $10.8 \%$ of the patients had a history, including $2.4 \%$ of pregnancy. Poor oral hygiene was found in $95.2 \%$ of patients and $31.3 \%$ consumed alcohol, $18.1 \%$ tobacco and $2.4 \%$ drugs. We counted a total of $56.6 \%$ of peri-mandibular cellulitis. The majority were diffuse cellulitis (78.9\%) (Table 2).

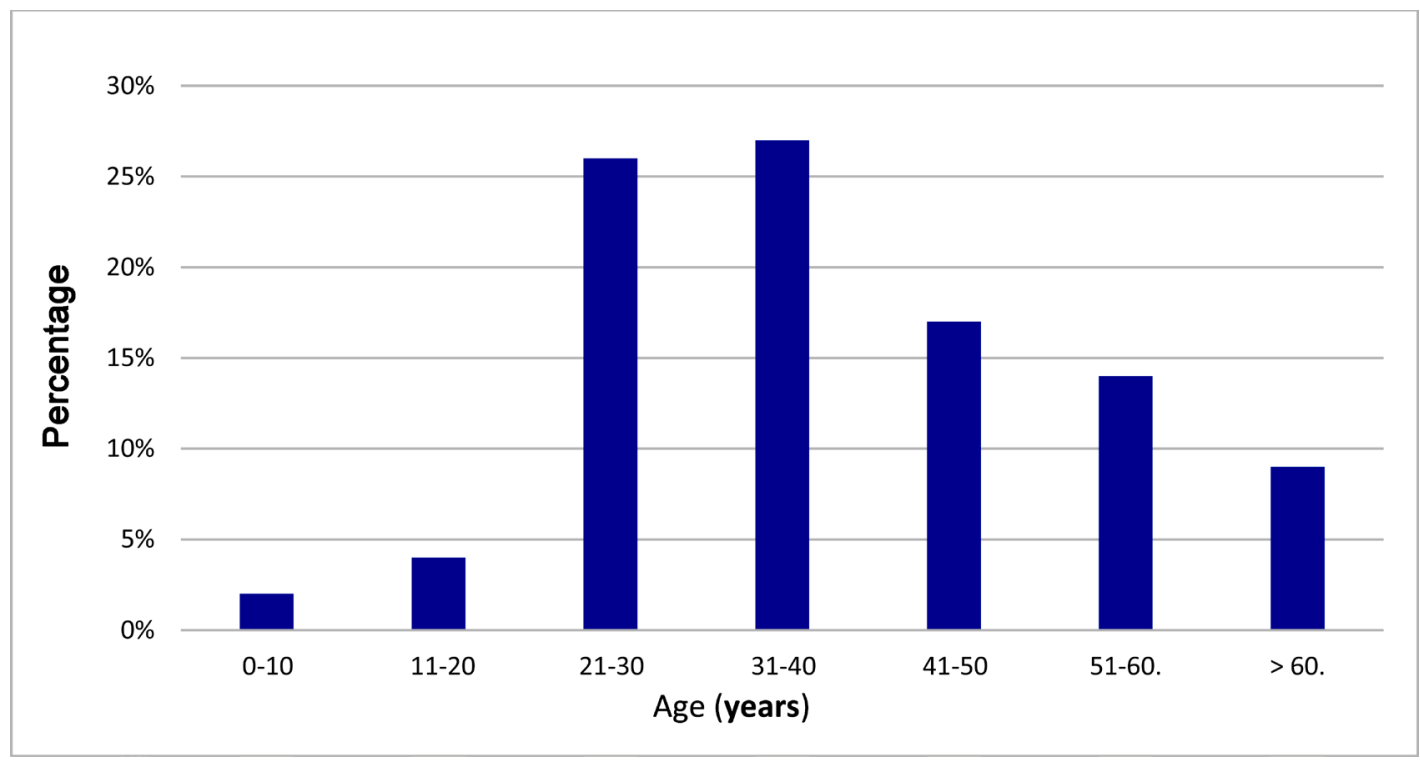

Figure 1. Age distribution of patients. 
Table 1. Distribution of patients according to socio-demographic characteristics.

\begin{tabular}{|c|c|c|}
\hline Variables/Modalities & Number $(n=166)$ & Percentage \\
\hline \multicolumn{3}{|l|}{ Gender } \\
\hline Male & 120 & 72.3 \\
\hline Female & 46 & 27.7 \\
\hline \multicolumn{3}{|l|}{ Marital status } \\
\hline Alone & 36 & 21.7 \\
\hline In Couple & 130 & 78.3 \\
\hline \multicolumn{3}{|l|}{ Study level } \\
\hline Not in school & 86 & 51.8 \\
\hline Primary school & 63 & 38.0 \\
\hline High school and above & 17 & 10.2 \\
\hline \multicolumn{3}{|l|}{ Profession } \\
\hline Salaried employee & 10 & 6.0 \\
\hline Self-employed & 111 & 66.9 \\
\hline No remuneration & 39 & 23.5 \\
\hline Others & 6 & 3.6 \\
\hline \multicolumn{3}{|l|}{ Resources } \\
\hline Indigent & 98 & 59.0 \\
\hline Assurance & 2 & 1.2 \\
\hline Personal & 66 & 39.8 \\
\hline \multicolumn{3}{|l|}{ Residence area } \\
\hline \multicolumn{3}{|l|}{ Burkina } \\
\hline Urban & 117 & 70.5 \\
\hline Semi-Urbain & 36 & 21.7 \\
\hline Rural & 10 & 6.02 \\
\hline Côte d'Ivoire & 3 & 1.8 \\
\hline
\end{tabular}

\section{Hematological characteristics}

Patients with blood types B+ and O+ represented $33.77 \%$ and $31.13 \%$ of our sample respectively. Red blood cell count was low in $55.5 \%$ of patients and polycythemia was noted in $5.5 \%$ of patients. Hyperleukocytosis was present in $89.16 \%$ of patients, neutrophilic polynucleosis in $81.25 \%$ and hyperlymphocytosis in $10.8 \%$. Platelets were normal in $43.14 \%$ of patients and $78.43 \%$ of patients had a decreased hematocrit (hemodilution). Anemia was noted in 64.7\%) of patients, the average corpuscular volume was low (microcytosis) in $35.5 \%$ and $38.24 \%$ had low average corpuscular hemoglobin content (MCHC). In addition, $15.69 \%$ of patients had hypochromia (Table 3 ).

\section{Biochemical characteristics}

Hyperglycemia was found in $48 \%$ of tested patients. Uricemia was elevated in $61.0 \%$ as well as $31.17 \%$ had elevated creatinemia (Table 4 ). 
Table 2. Distribution of patients according to clinical characteristics.

\begin{tabular}{lcr}
\hline Variables/Modalities & Number $(\mathbf{n}=166)$ & Percen \\
\hline Reason for consulting & 153 & \\
Pain & 13 & 72.2 \\
Swelling & & \\
Consultation deadlines & 133 & 80.1 \\
First week & 20 & 12.1 \\
Second week & 13 & 7.8 \\
Third week and above & 18 & 10.8 \\
Medical history & 4 & 2.4 \\
Diabetes & 3 & 1.8 \\
Cardiovascular disease & 4 & 2.4 \\
Pregnancy & 1 & 0.6 \\
Kidney disease & 2 & 1.2 \\
Mental illness & 4 & 2.4 \\
Others & &
\end{tabular}

Oral hygiene

Good

Poor

95.2

Alcohol intake

Yes

No

Tobacco use

Yes

No

Drug use

Yes

No

Clinical forms

Circumscribed

Diffuse

Topography

Peri-maxillary

Peri-mandibular

Cervico-thoracic

Others ${ }^{* *}$ 
Table 3. Distribution of patients according to hematological data.

\begin{tabular}{c}
\hline Variables/Modalities \\
\hline Blood Types/Rhesus \\
A+ \\
AB+ \\
B- \\
B+ \\
O- \\
O+ \\
Red blood cells \\
Polycythemia \\
Lowered \\
White blood cells \\
Hyperleukocytosis \\
Leukopenia \\
Neutrophils (PNN) \\
Polynucleosis \\
Neutropenia \\
Lymphocytes \\
Hyperlymphocytosis \\
Lymphopenia
\end{tabular}

Platelets

Hyperplateletosis

Thrombocytopenia

\section{Hematocrit}

Hemoconcentration

Hemodilution

\section{Hemoglobin}

Polyglobulin

Anemia

Mean Blood Volume (MBV)

Macrocytosis

Microcytosis

Mean corpuscular content (MCC)

Macrocytosis

Hypochromia

Mean corpuscular hemoglobin concentration (MCHC)

High

Hypochromia

HIV serology
Number $(\mathbf{n}=151) \quad$ Percentage

$\begin{array}{cc}34 & 22.5 \\ 15 & 10.0 \\ 2 & 1.3 \\ 51 & 33.8 \\ 2 & 1.3 \\ 47 & 31.1\end{array}$

$(\mathrm{n}=166)$

9

92

$(\mathrm{n}=166)$

148

89.16

2

$(\mathrm{n}=160)$

130

(n = 102)

11 10.8

6

$(\mathrm{n}=102)$

44

43.1

5

$(\mathrm{n}=102)$

0

0

80

78.4

$(\mathrm{n}=102)$

0

66

\section{0}

0

36

35.3

$(\mathrm{n}=102)$

2.9

$(\mathrm{n}=102)$

12

16

$(\mathrm{n}=22)$

Positive

0

0 
Table 4. Distribution of patients according to biochemical data.

\begin{tabular}{lcc}
\hline Variables/Modalities & Number $(\mathbf{n}=2)$ & Percentage \\
\hline CRP & 1 & 50.0 \\
$\quad$ High & $(\mathrm{n}=154)$ & \\
Blood glucose & 74 & 48.0 \\
$\quad$ Hyperglycemia & 10 & 6.5 \\
$\quad$ Hypoglycemia & $(\mathrm{n}=140)$ & 61.0 \\
Uremia & 85 & 7.0 \\
$\quad$ High & 10 & \\
$\quad$ Lowered & $(\mathrm{n}=154)$ & 31.17 \\
Creatinemia & 48 & 20.78 \\
$\quad$ High & 32 & \\
Lowered & &
\end{tabular}

\section{Discussion}

Our study, which aimed to describe the hematological and biochemical variations of cervicofacial cellulitis of dental origin in UHC-YO and UHC-B, has some limitations that are worth discussions. The small sample size of 166 subjects is the first limitation of our study. There is a recruitment bias due, on one hand, to the impossibility for some patients to perform biological examinations and, on the other hand, to the repeated absence of reagents in the above-mentioned subsidized centers. However, the 2 centers have a quasi-exhaustive recruitment of this pathology because they are accessible and available reference centers, so this could limit this bias.

\section{Socio-demographic characteristics}

Cervicofacial cellulitis affects patients of all ages, but predominates in young subjects, which was noted in our study [6]. The male predominance found in the literature, Zawiślak [4] in Poland, Bissa [13] in Togo and Benzarti [14] in Tunisia, is also noted in our results. This could be explained by the neglect of oral hygiene measures by men but also by the high consumption of tobacco and alcohol, which are incriminating factors in cellulitis [15]. In women, in addition to hygiene, a better immune response has also been mentioned by some authors [14] [16].

The low socio-economic and educational levels of our patients also play an important role in the genesis of cervicofacial cellulitis [15]. Indeed, the lack of financial means, which does not allow access to adequate care, often leads to self-medication and recourse to traditional therapists for the management of these infections. In our series, the number of cases of cellulitis decreased with the level of education, which could be explained by the fact that the more educated people are, the more they pay attention to their oral health.

\section{Clinical characteristics}

The reasons for consultation found in our study were pain $(92.17 \%$ of pa- 
tients), and swelling ( $7.83 \%$ of patients). These results could be explained by the fact that in our context of ignorance and poverty, only embarrassing and/or disabling signs motivate the majority of patients to consult [7]. $80.2 \%$ of the patients consulted in the first week, and only $12.05 \%$ in the second week. The fact that $63.25 \%$ of our patients lived in Ouagadougou would be the reason for this high consultation rate in the first week. $95.18 \%$ of the patients had poor oral hygiene, $52.41 \%$ practiced self-medication, $31.3 \%$ drank alcohol, and $18.07 \%$ were smokers. These results are highly significant and only support the data in the literature regarding the role of defective hygiene, alcohol and smoking as factors favoring the occurrence of cellulitis [12] [17]. The peri-mandibular region was the most affected in our study with $56.63 \%$ of cases followed by the peri-maxillary region with $25.3 \%$. This can be explained by the fact that the origin of the local infection is very often a posterior mandibular tooth, and the diffusion is more easily towards these regions, in the direction of the cellulosic flows [4] [18] [19] [20]. Diffuse forms (78.92\%) were more numerous than circumscribed forms (21.08\%). This could be explained by the preponderance in our study of favourable factors such as self-medication with NSAIDs, smoking, traditional therapy. These factors weaken the host immune response, thus leading to the emergence of severe forms [7] [19] [21].

\section{Hematological characteristics}

More than half of our patients (55.42\%) had a low red blood cell count and 9 (5.42\%) had polycythemia. This decrease in red blood cells could be explained by the presence of bleeding (3.61\%) which is responsible for the decrease in the figurative elements of the blood. This bleeding, when important, can be responsible for hypotension with or without renal damage.

The majority of our patients $(89.16 \%)$ had a hyperleukocytosis on the blood count. The elevation of the white blood cell count is frequent in cellulitis [4] [6], it shows the extent of the infectious process and is due to an increase in the number of neutrophils. In the most severe cases, sepsis with multivisceral failure (mediastinitis, cervical infection, etc.) can occur, which can rapidly lead to death in the absence of adequate therapeutic measures. In our series, the figures are higher than those presented by Sawadogo [21] and El Ayoubi [16] in their studies which found respectively a hyperleukocytosis in $77.83 \%$ and $73 \%$ of the patients. Our results are lower than those of Diarra [22] who found hyperleukocytosis in $96.6 \%$ of cases.

In our study $83.3 \%$ of patients had normal lymphocyte counts; $10.8 \%$ had hyperlymphocytosis. This could be explained by the fact that cervicofacial cellulitis of dental origin is mainly due to bacteria including group $B$ streptococcus and/or staphylococcus Aureus. As a rule, lymphocyte levels increase in response to viral stimuli. The increased number of lymphocytes could be due to a viral attack, particularly of the ENT sphere, evolving concomitantly with the cellulitis.

About $43.14 \%$ of the patients in our study had hyperplaquettosis. This is a reactive thrombocytosis which could be explained not only by the chronic in- 
flammation but also by the infectious syndrome following the cellulitis. It can be the cause of numerous complications including thrombosis of the vessels of the face such as the cavernous sinus and the facial vein, with a consequent drainage deficit in the anatomical area concerned. Hyperplaque may also result in bruising or mucocutaneous hemorrhages such as nosebleeds or gum bleeds.

In our study $78.43 \%$ had a lowered hematocrit (hemodilution). This could be explained by several factors the clinical anemic syndrome seen on clinical examination marked by skin and mucous membrane pallor in $72.89 \%$ of cases. The decrease in hematocrit level often reflects anemia.

Anemia was noted in $64.7 \%$ of our patients. The clinical signs of anemia were observed in several of our patients, including the paleness of the conjunctiva, asthenia, the presence of bleeding, and the presence of pregnant women. Here we have anemia by blood spoliation due to bleeding. If not managed, it can potentially lead to cardio-respiratory complications, in particular dyspnea, tachycardia, palpitation, neurological complications with consciousness disorders, but also renal complications, as hypovolemia will eventually lead to functional renal failure. These rates that we report in our study are higher than those of Sawadogo [21] and Konsem [18] who found anaemia at the haemogram respectively in $46.55 \%$ and $8 \%$ of their patients.

HIV infection is a significant factor in the development of CCF, as it leads to a progressive deficit in cellular immunity. HIV-positive patients have an increased susceptibility to opportunistic infections. Moreover, it has been shown that seropositivity increases the risk of developing severe forms of CCF [22]. Among 22 patients tested, none was seropositive. Kouakou [23] found a seropositivity rate of $14.49 \%$. Badou [24] found $9.6 \%$ of patients to be HIV positive.

Microcytosis (35.5\% of patients in our study) could be explained by the chronicity of inflammatory anemia and excessive iron storage in the liver reserves.

The most affected blood groups in our study were $\mathrm{B}+(33.77 \%)$ and $\mathrm{O}+$ (31.13\%). In the absence of sufficient data in the literature on the correlations that could exist between blood grouping and cellulitis, we can only limit ourselves to this observation, hoping that further studies will provide sufficient evidence on the existence or not of a correlation between blood grouping and genesis of dental CCFs.

\section{Biochemical characteristics}

C-reactive protein (CRP) was not systematically requested. Indeed, this determination is justified for the research and the follow-up of an inflammatory process. Moreover, the precariousness of the situation led the patients to carry out only the most urgent examinations. CRP has an opsonizing action favoring the phagocytosis of apoptotic cells and activates the T complement.

Hyperglycemia (48.0\%) was found in 4 patients. El Ayoubi [16] found hyperglycemia in $20 \%$ of cases, hypoglycemia was found in $1.7 \%$ of patients. Blood glucose disorders involve the regulatory mechanism of the pancreas, whose insulin ensures the lowering of blood glucose and promotes the use of glucose by the tissues. Diabetes resulting from chronic hyperglycemia is one of the factors fa- 
voring cellulitis reported by several authors [25] [26] [27].

The high rate of uricemia (61\%) could be explained by the extensive tissue necrosis that takes place during the pathology. Its increase in the blood is synonymous with renal damage and or hypercatabolism situation as it is the case in our study. The increase of creatinemia could be explained by a progressive deterioration of the kidneys due to the joint action of the factors mentioned above. In the absence of management, the symptoms evolve towards parenchymal renal failure. In the literature, Sawadogo [21] found an increase in creatinemia in $15.33 \%$ of cases.

\section{Conclusion}

Cellulitis is a pathology that is still frequent in less privileged environments. It affects mainly young male adults but can affect both men and women, regardless of age. Its diagnosis can be guided by clinical and biological findings. Anemia, hyperleukocytosis and hyperplateletosis, and hypercreatinemia can be life-threatening if not well controlled. In addition, the consumption of alcohol, tobacco and certain comorbidities such as diabetes are aggravating factors that can cause the appearance of complicated forms. A consequent education of the population on oral health, and the control of the biological disorders which result from it are sufficient to strongly decrease its prevalence and the appearance of complicated forms.

\section{Conflicts of Interest}

The authors declare no conflicts of interest regarding the publication of this paper.

\section{References}

[1] Blancal, J.-P., Kania, R., Sauvaget, E., Huy, P.T.B., Mateo, J., Guichard, J.-P., et al. (2010) Prise en charge des cellulites cervicofaciales en réanimation. Réanimation, 19, 297-303. https://doi.org/10.1016/j.reaurg.2010.04.001

[2] Razafindrabe, J., Randriamanantenasoa, V., Andrianasolo, M., Radaviarison, J., Rasoarimasy, V. and Rakotovao, J. (2007) Epidemiological and Clinical Aspect of Dental Cellulitis in Antananarivo. Journal of Medical Sciences, 7, 1108-1111. https://doi.org/10.3923/jms.2007.1108.1111

[3] Fofana, A., Keita, M., Beye, S., Doumbia-Singaré, K., Drame, B., Timbo, S., et al. (2017) La Cellulite cervico-faciale et thoracique en milieu défavorisé à Ségou au Mali. Revue Malienne d Infectiologie et de Microbiologie, 9, 2-10.

[4] Zawiślak, E. and Nowak, R. (2021) Odontogenic Head and Neck Region Infections Requiring Hospitalization: An 18-Month Retrospective Analysis. BioMed Research International, 2021, Article ID: 7086763. https://doi.org/10.1155/2021/7086763

[5] Alotaibi, N., Cloutier, L., Khaldoun, E., Bois, E., Chirat, M. and Salvan, D. (2015) Criteria for Admission of Odontogenic Infections at High Risk of Deep Neck Space Infection. European Annals of Otorhinolaryngology, Head and Neck Diseases, 132, 261-264. https://doi.org/10.1016/j.anorl.2015.08.007

[6] Bertolus, C. (2011) Cellulite Cervico-Faciale. Conférences. Infections cutanées. URGENCES 2011, Vol. 52, Paris, 593-600. 
[7] Keita, A., Fofana, M., Diallo, I., Diallo, M., Keita, M. and Fofana, F. (2018) Les cellulites cervico-faciales: Facteurs favorisants, aspects épidémiologique, clinique, thérapeutique et évolutive au service d'Otorhinolaryngologie et de Chirurgie Cervico-Faciale de l'Hôpital Régional de Kankan, Guinée-Conakry. Jaccr Africa, 2, 261-268.

[8] Cavaillon, J.-M. (2005) Médiateurs de l'inflammation. In: Martin, C. and Vincent, J.-L., Eds., Sepsis sévère et choc septique, Springer, Paris, 23-49.

https://doi.org/10.1007/2-287-27496-0 2

[9] Traore, I., Beogo, R., Traore, A., Coulibaly, T., Millogo, M. and Ouedraogo, N. (2012) Caractéristiques et déterminants de la létalité de la cellulite aiguë diffuse de la face. Revue Internationale du College D'Odonto-Stomatologie Africain et de Chirurgie Maxillo-Faciale, 19, 20-23.

[10] Eboungabeka Trigo, E., Mabika, B., Bancolé Pognon, S., Moussa, M. and Magnomé, J. (2020) Les Cellulites Cervico-Faciales chez la Femme enceinte au CHU de Brazzaville: A Propos de 31 Cas. Health Sciences and Disease, 21, 82-87.

[11] Garé, J., Guiguimdé, W., Millogo, M., kouamé, P. and Konsem, T. (2019)Facteurs associés à la mortalité des cellulites cervicofaciales dans le service de stomatologie et de chirurgie maxillofaciale du Centre Hospitalier Universitaire Yalgado Ouédraogo (CHU-YO). Revue Ivoirienne d Odonto-Stomatologie, 21, 33-41.

[12] Bennani-Baïti, A.A., Benbouzid, A. and Essakalli-Hossyni, L. (2015) Cervicofacial Cellulitis: The Impact of Non-Steroidal Anti-Inflammatory Drugs. A Study of 70 Cases. European Annals of Otorhinolaryngology, Head and Neck Diseases, 132, 181- 184. https://doi.org/10.1016/j.anorl.2015.06.004

[13] Bissa, H., Adam, S., Amana, B., Winga, F., Essobozou, P., Lawson, L., et al. (2019) Cellulites Cervico-Faciales D'origine Dentaire au CHU Sylvanus Olympio de Lome Au Togo. European Scientific Journal, ESJ, 15, 70-80. https://doi.org/10.19044/esj.2019.v15n36p70

[14] Benzarti, S., Mardassi, A.,Mhamed, R,. Hachicha, A., Brahem, H., Akkari, K., et al. (2007) Les cellulites cervico-faciales d'origine dentaire: A propos de 150 cas. J Tunis ORL Chir Cervico-Faciale, 19, 24-25.

[15] Institut national d'excellence en santé et en services sociaux (INESSS) (2017) Cellulite infectieuse chez l'adulte et l'enfant. Institut national d'excellence en santé et en services sociaux (INESSS), Québec, 1-92.

[16] El Ayoubi, A., El Ayoubi, F., Mas, E., Guertite, A., Boulaïch, M., Essakalli, L., et al. (2009) Cellulites cervico-faciales diffuses d'origine dentaire: A propos de 60 cas. Médecine Buccale Chir Buccale, 15, 127-135.

[17] Haitami, S., Kissi, L., Hamza, M., Rifki, C. And Yahya, I.B. (2016) Les cellulites cervico-faciales d'origine dentaire: Etude transversale. Revue d OdontoStomatologie, 45, 300-309.

[18] Konsem, T., Millogo, M., Ouédraogo, D., Zidwemba, N. and Ouoba, K. (2012) Les cellulites diffuses cervico-faciales au centre hospitalier universitaire Yalgado Ouédraogo (Ouagadougou Burkina Faso). Revue Internationale du College D' Odonto-Stomatologie Africain et de Chirurgie Maxillo-Faciale, 19, 303-304.

[19] Ngouoni, B., Ngotne, R., Mbitsi-Ngoma, H. and Mosimbi, N. (2008) Cellulites diffuses sous mandibulaires d'origine dentaire. Revue Internationale du College D'Odonto-Stomatologie Africain et de Chirurgie Maxillo-Faciale, 15, 38-42.

[20] Bengono, C., Bita, R., Avang, N., Mengong, H. and Bengono, G. (2006) Cellulites et phlegmons d'origine dentaire au CHU de Yaoundé. Odonto-Stomatol Trop Trop Dent J, 113, 23-26. 
[21] Sawadogo, R. (2018) Cellulites cervico-faciales graves d'origine dentaire: Aspects épidémiologiques, cliniques et prise en charge dans le Service de Stomatologie et de Chirurgie Maxillo-Faciale (S/CMF) du Centre Hospitalier Universitaire Yalgado OUEDRAOGO (CHU/YO). Thèse de médecine, Université Ouaga I Pr Joseph Ki ZERBO, Ouagadougou-Burkina Faso.

[22] Diarra, K. (2015) Cellulites Cervicales Diffuses: aspects épidémiologique clinique et thérapeutique dans le Service ORL-CCF CHU Gabriel TOURE. Thèse de Médecine, Université des sciences, des techniques et des technologies de Bamako, Bamako-Mali.

[23] Kouakou, K., Ouattara, B., Sidibé, O., Boka, B., Daweni, J. and Koffi, M. (2018) Cellulites cervico-faciales diffusées et nécrosantes: aspects épidémiologiques, cliniques et thérapeutiques en 15 ans au CHU de Cocody (Côte d'Ivoire). Revue Internationale du College D'Odonto-Stomatologie Africain et de Chirurgie Maxillo-Faciale, 25, 5-9.

[24] Badou, K., Buraima, F., Yoda, M., Traore, K., Kouassi, Y, Tanon-Anoh, M., et al. (2014) Cellulites cervico-faciales au centre hospitalo-universitaire de Yopougon (Abidjan-cote d'ivoire). Revue Internationale du College D'Odonto-Stomatologie Africain et de Chirurgie Maxillo-Faciale, 21, 5-10.

[25] Dédjan, A.-H., Haraj, N.-E., El Aziz, S. and Chadli, A. (2016) Les cellulites cervico-faciales chez le diabétique. Médecine des Maladies Métaboliques, 10, 309-313. https://doi.org/10.1016/S1957-2557(16)30117-1

[26] Assouan, C., Anzouan-Kacou, E., Aka-Adouko, J., Millogo, M., N'guessan, D., DIOMANDE, A., et al. (2012) Prise en charge des cellulites chez le diabétique. Revue Internationale du College D'Odonto-Stomatologie Africain et de Chirurgie Maxillo-Faciale, 19, 16-19.

[27] Diallo, O., Balde, N., Condé, B., Camara, S. and Bah, A. (2006) Les cellulites cervico-faciales chez le patient diabetique au chu de Conakry. Revue Internationale $d u$ College D'Odonto-Stomatologie Africain et de Chirurgie Maxillo-Faciale, 13, 13-16.

\author{
Annex \\ https://docs.google.com/document/d/13BOeqHIFvcto0KwaYhrym7hkpK7sl-pm \\ ledit?usp $=$ sharing\&ouid $=103872500155260047162 \& \mathrm{rtpof}=$ true $\& s d=$ true
}

